\title{
Physio-Chemical and Toxicological Study of the Water of the Lubumbashi River, in Democratic Republic of Congo
}

\author{
Lakula Niclette1, Kasongo Pembi Christian1, Kangabuka Shishi Maguy1, \\ Bondo Kalumba Clarisse ${ }^{2}$, Tambwe Ndjakanyi Pierre ${ }^{3}$, Nzeba Tshibanda Christelle3, \\ Kataka Zabadi Kleph ${ }^{3}$, Kaki Khangmariette ${ }^{4}$, Khang Imvar Esther ${ }^{3}$, \\ Wetchi Ongona Tchomba Andre ${ }^{3}$, Mazono Mbang Pierre ${ }^{3}$, Katumbo Mukemo Astrid4, \\ Kabamba Nzaji Michel5, Luboya Numbi Oscar6
}

\footnotetext{
${ }^{1}$ Department of Nutrition and Dietetics, Technical Management Division Biomédiales, Institute of Higher Medical Techniques of Lubumbashi, Lubumbashi, Democratic Republic of Congo

${ }^{2}$ Management Department of Sanitary Institutions, Technical Management Division Biomédiales, Institute of Higher Medical Techniques of Lubumbashi, Lubumbashi, Democratic Republic of Congo

${ }^{3}$ Department of Medical Biology, Technical Management Division Biomédiales, Institute of Higher Medical Techniques of Lubumbashi, Lubumbashi, Democratic Republic of Congo

${ }^{4}$ Department of Education Administration in Nursing, Nursing Section, Institute of Higher Medical Techniques of Lubumbashi, Lubumbashi, Democratic Republic of Congo

${ }^{5}$ Department of Public Health, Faculty of Medicine, University of Kamina, Kamina, Democratic Republic of Congo

${ }^{6}$ Department of Public Health, Faculty of Medicine, University Lubumbashi, Lubumbashi, Democratic Republic of Congo

Email: michelnzaji@yahoo.fr
}

How to cite this paper: Niclette, L., Christian, K.P., Maguy, K.S., Clarisse, B.K., Pierre, T.N., Christelle, N.T., Kleph, K.Z., Khangmariette, K., Esther, K.I., Andre, W.O.T., Pierre, M.M., Astrid, K.M., Michel, K.N. and Oscar, L.N. (2017) Physio-Chemical and Toxicological Study of the Water of the Lubumbashi River, in Democratic Republic of Congo. Open Access Library Journal, 4: e3562.

https://doi.org/10.4236/oalib.1103562

Received: March 27, 2017

Accepted: May 23, 2017

Published: May 26, 2017

\begin{abstract}
The absolute necessity of water in the life of man remains undeniable to the point that some people think the water is the life. Metals are ubiquitous in surface waters. But their concentrations are generally very low which explains their name "trace metals" or "trace metals". However, when the mining begins operating a metal-rich deposit, a change operates especially in waters in contact with these mining works. This study aims to determine the $\mathrm{pH}$ of the river water Lubumbashi, and then measure the accumulation of trace elements in the food chain in order to evaluate the risks to human health. The $\mathrm{pH}$ of the recorded values are within normal limits (6.5 - 9.5); Site 1 has an average $\mathrm{pH}$ of $7.962( \pm 0.185)$; the site 2 and $3 \mathrm{had}$ a $\mathrm{pH}$ of $8.140( \pm 0.210)$ and 8.331 $( \pm 0.082)$ respectively. The samples of water show very low levels of metals which not exceed normal values with the exception of the $\mathrm{Cd}$. This mineral element presents concentrations higher than $0.003 \mathrm{mg} / \mathrm{l}$. The $\mathrm{pH}$ of the river Lubumbashi water meets drinking water standards accepted by the WHO. The Cd that has very high concentrations may contribute to the pollution of
\end{abstract}


Copyright $\odot 2017$ by authors and Open Access Library Inc.

This work is licensed under the Creative Commons Attribution International

License (CC BY 4.0).

http://creativecommons.org/licenses/by/4.0/ the river Lubumbashi. Note that the STL plant contributes significantly to the alkalizing and pollution water following these liquids tributaries.

\section{Subject Areas}

Nutrition, Public Health

\section{Keywords}

Quality Physico-Chemical of Water, Toxicology, River Lubumbashi

\section{Introduction}

Water is essential for human life, animals and plants. Its quality is a universal health problem. It is essential for life, but it can convey and transmit diseases in the countries of all the continents of the poorest to the richest [1].

Population growth in developing countries is accompanied by a problem that is often poorly managed: management of solid and liquid waste. These wastes continue to be discharged untreated into the course (lagoons), and plans water (lakes) of some large cities of Africa, posing serious health problems according to the report of the assessment of development progress sustainable in Africa [2].

Among the major contaminants of environment, heavy metals pose serious environmental problems, as the ubiquity of their presence within the biosphere as their toxicity and bioaccumulation potential in several aquatic species inducing a devastating effect on the balance ecological of aquatic environment [3] [4].

Contamination of aquatic ecosystems by metals ( $\mathrm{Mn}$. Ni. Cr. Cu. $\mathrm{Zn}$. Pb) remains a serious environment problem increasingly worrying. In some aquatic ecosystems, these chemicals can be responsible for the disappearance of certain animal species and/or plant and therefore cause the malfunction of the trophic chain (low biodiversity...) [5].

The African case is more worrisome because the vulnerability of states lacks the financial means and techniques sometimes require the restoration of polluted aquatic site. The metals are present in all areas of aquatic ecosystem in the world (water, sediment, flora and fauna) [6]. According Forstner and Wittman (1981), a large fraction of heavy metals in the aquatic environment are associated with a reversible manner to the surface sediments [7].

The problems caused by the dispersion of pollutants in the environment arouse the interest of the scientific community for many years now as the protection of environment requires knowledge of the fate of these pollutants in environment and their effects on aquatic ecosystems.

Among the major contaminants of environment, heavy metals pose serious environmental problems as the ubiquity of their presence within the biosphere as their toxicity and bioaccumulation potential in several aquatic species inducing a devastating effect on the balance ecological of aquatic environment [3] [4]. 
In these recent years, there has been an intensification of "mining in the copper belt in Katanga. Among the minerals mined, what to be mentioned is copper $(\mathrm{Cu})$, cobalt $(\mathrm{Co})$, zinc $(\mathrm{Zn})$, lead $(\mathrm{Pb})$, the uranium $(\mathrm{U})$, the arsenic $(\mathrm{As})$ and cadmium (Cd) (2).

In order to evaluate the state of the heavy metal pollution $(\mathrm{Mn}, \mathrm{Ni}, \mathrm{Cr}, \mathrm{Cu}, \mathrm{Zn}$ and $\mathrm{Pb}$ ) and their distribution in the sediments of the estuary Comoé Keiba Noel Keumean et al. showed contamination in order $\mathrm{Pb}>\mathrm{Ni}>\mathrm{Cu}$ in the index geoaccumulation and runoff constitutes a source of contamination of estuary and its sediment [5]. While for Cyriaque Degbey, concentrations of heavy metals in the exception of mercury and cadmium were lower in the water and elevated in sediments at stations of mouth (K15 and K16) [8].

In Lubumbashi, mill effluents contain heavy metals which are discharged untreated into the waters of the city of Lubumbashi in general and the river Lubumbashi in particular. So to maintain the quality of fish products, it is important to assess the level of pollution courses water and the food chain. This study has the objective of determining the $\mathrm{pH}$ of the river Lubumbashi water, and then measuring the accumulation of trace elements in the food chain in order to evaluate the risks to human health.

\section{Material and Method}

\subsection{Description of the Environment of Study}

Located at 1230 meters altitude, the city of Lubumbashi covers an area of 747 $\mathrm{km}^{2}$. It is characterized by geographical coordinates after: $11^{\circ} 39^{\prime} 57^{\prime \prime}$ south latitude, $27^{\circ} 28^{\prime} 35^{\prime \prime}$ east longitude, $27^{\circ} 30^{\prime}$ west longitude and $11^{\circ} 36^{\prime}$ north latitude.

The floor of the city of Lubumbashi is both alluvial, sandy-clay and silt-clay with a relief of valleys in some places and the dominant vegetation is woodland. The province of Haut-Katanga is characterized by the presence of a copper arc in which several hills are rich in minerals (copper. cobalt. zinc. iron...) and other important metals attract much investment.

North to north-west to south-east, the city of Lubumbashi is crossed by two major rivers: Kafubu and Lubumbashi. It also has five low flow streams in the dry season; it is Kamalondo, Ruashi, Kimilolo, Naviundu and Katuba.

\subsection{Sampling}

As part of our work, the basic material that is the subject of Research consists essentially of water samples from the river Lubumbashi. We Samples were collected at three sites, namely:

- The site I: River Lubumbashi opposite Tshondo school; it is-to-say upstream of point from which the mixture of river water with the liquid effluent from the STL factory;

- The site II: Lubumbashi in the river a few meters of the discharge drain waste water from the factory STL; it is-to-say downstream of water mixing point of the river with effluent from the plant;

- The site III Lubumbashi in the river at the bridge on Katuba Boulevard in 
more than $300 \mathrm{~m}$ of water mixing point of the river with the liquid effluent from the plant.

Five samples of water were sampled per sampling site and numbered as follows: Ech1, Ech2, Ech3, Ech4 and Ech5. Given the diversity of the nature of natural waters, it is difficult to define a satisfactory sampling technique in all circumstances [9]. To do this, we chose the method of instantaneous manual sampling. The water samples were collected in sterilized bottles, made of polyethylene of $500 \mathrm{ml}$ capacity. These were first rinsed with water from the river, then filled and hermetically sealed. All samples were taken with a 2 meter stick at the end of which we attached a bottle placed in the opposite direction of the stream of water. The samples were taken between 6:30 am and 7:30 am during the period from February 2016 to May 2016. The samples were finally sent to the chemical laboratory of the Congolese Control Office (OCC) in Lubumbashi for Determination of $\mathrm{pH}$ and the detection of heavy metals.

The $\mathrm{pH}$ measurement was carried out by the potentiometric method using a Consort $\mathrm{pH} / \mathrm{EC}$ meter $\mathrm{C} 732 \mathrm{pH}$ meter. The mineral elements were determined by Inductively Coupled Atomic Emission Spectrophotometry (ICP) on the Perkin Elmer Sciex brand Elan DRC II model. The statistical analysis of the studied parameters consisted of the comparison of the means of samples by the Student test.

\section{Results}

\section{a. $\mathrm{pH}$ measurement}

The physicochemical analysis of Lubumbashi River water consisted in the determination of $\mathrm{pH}$. The results are reported in Table 1. By observing the table below-above, it appears that the recorded $\mathrm{pH}$ values are within the normal limits (6.5 - 9.5). In fact, the site I showed an average $\mathrm{pH}$ of $7.962( \pm 0.185)$; while that it is respectively $8.140( \pm 0.210)$ and $8.331( \pm 0.082)$ for the II and III sites. The $\mathrm{pH}$ tends to increase from the site I to III website.

\section{a. Determination of heavy metals in river water Lubumbashi}

We continued our investigations by the presence of heavy metals in different water samples from the river Lubumbashi. These chemical analyzes were used to determine the levels of $\mathrm{Fe}$. $\mathrm{Cu}$. Co. $\mathrm{Zn}$. $\mathrm{Mn}$. $\mathrm{Cr}$. $\mathrm{Pb}$. Cd and led to results which are shown in Tables 2(a)-2(c).

Table 1. Measuring $\mathrm{pH}$ of river water Lubumbashi.

\begin{tabular}{ccccc}
\hline Sample No. & Site I & Site II & Site III & WHO standards \\
\hline 1 & 8.161 & 8.189 & 8.327 & \\
2 & 8.057 & 8.42 & 8.37 & \\
3 & 7.891 & 7.83 & 8.365 & \\
4 & 8.025 & 8.135 & 8.401 & 6.5 to 9.5 \\
5 & 7.68 & 8.126 & 8.192 & \\
$\begin{array}{c}\text { Average (Y) and } \\
\text { standard deviation }\end{array}$ & $\mathbf{7 . 9 6 2 \pm 0 . 1 8 5}$ & $\mathbf{8 . 1 4 0 \pm 0 . 2 1 0}$ & $\mathbf{8 . 3 3 1 \pm 0 . 0 8 2}$ & \\
\hline
\end{tabular}


Table 2. (a) Level (in \%) of heavy metals in the site I. (b) b: level (in \%) of heavy metals in the site II; (c) content (in \%) of heavy metals in the site III.

(a)

\begin{tabular}{|c|c|c|c|c|c|c|c|c|}
\hline $\begin{array}{c}\text { Heavy metals } \\
\text { Sample }\end{array}$ & $\mathrm{Fe}$ & $\mathrm{Cu}$ & Co & $\mathrm{Zn}$ & $\mathrm{Mn}$ & $\mathrm{Pb}$ & $\mathrm{Cr}$ & $\mathrm{Cd}$ \\
\hline 1 & 0.147 & 0.013 & 0.004 & 0.009 & 0.005 & - & 0.009 & 0.005 \\
\hline 2 & 0.115 & 0.028 & 0.004 & 0.04 & 0.004 & 0.003 & 0.005 & 0.005 \\
\hline 3 & 0.02 & 0.002 & 0.002 & 0.071 & 0.002 & 0.002 & 0.003 & 0.004 \\
\hline 4 & 0.121 & - & - & 0.027 & 0.003 & 0.005 & 0.005 & 0.004 \\
\hline 5 & 0.236 & 0.001 & 0.001 & 0.011 & 0.003 & 0.001 & 0.006 & 0.002 \\
\hline
\end{tabular}

Average

tstandard deviation

$0.128 \pm 0.0770 .011 \pm 0.014 \quad 07003 \pm 0.002 \quad 0.032 \pm 0.025 \quad 0.003 \pm 0.001 \quad 0.003 \pm 0.002 \quad 0.006 \pm 0.002 \quad 0.004 \pm 0.001$

WHO standards

$0.5-5.0 \quad 2$

1

0.4

0.05

0.01

0.01

0.003

(b)

\begin{tabular}{|c|c|c|c|c|c|c|c|c|}
\hline Heavy metals & \multirow[t]{2}{*}{$\mathrm{Fe}$} & \multirow[t]{2}{*}{$\mathrm{Cu}$} & \multirow[t]{2}{*}{ Co } & \multirow[t]{2}{*}{$\mathrm{Zn}$} & \multirow[t]{2}{*}{ Mn } & \multirow[t]{2}{*}{$\mathrm{Pb}$} & \multirow[t]{2}{*}{$\mathrm{Cr}$} & \multirow[t]{2}{*}{$\mathrm{Cd}$} \\
\hline Sample & & & & & & & & \\
\hline 1 & 0.13 & 0.006 & 0.002 & 0.058 & 0.006 & 0.007 & 0.006 & 0.006 \\
\hline 2 & 0.018 & 0.007 & - & 0.086 & 0.002 & 0.002 & 0.001 & 0.004 \\
\hline 3 & 0.127 & 0.001 & - & 0.039 & 0.003 & 0.003 & 0.005 & 0.003 \\
\hline 4 & 0.142 & - & 0.002 & 0.008 & 0.005 & 0.003 & 0.007 & 0.004 \\
\hline 5 & 0.115 & - & 0.004 & 0.01 & 0.007 & - & 0.01 & 0.006 \\
\hline
\end{tabular}

Average

\pm standard deviation

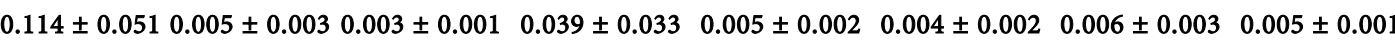

WHO standards $\quad 0.5-5.0$

2

(c)

(c)

\begin{tabular}{|c|c|c|c|c|c|c|c|c|}
\hline $\begin{array}{c}\text { Heavy metals } \\
\text { Sample }\end{array}$ & $\mathrm{Fe}$ & $\mathrm{Cu}$ & Co & $\mathrm{Zn}$ & $\mathrm{Mn}$ & $\mathrm{Pb}$ & $\mathrm{Cr}$ & $\mathrm{Cd}$ \\
\hline 1 & 0.551 & 0.021 & 0.01 & 0.028 & 0.047 & 0.005 & 0.002 & 0.003 \\
\hline 2 & 0.55 & 0.02 & 0.014 & 0.035 & 0.052 & absent & 0.002 & 0.004 \\
\hline 3 & 0.595 & 0.023 & 0.016 & 0.071 & 0.057 & absent & 0.002 & 0.009 \\
\hline 4 & 0.569 & 0.024 & 0.015 & 0.05 & 0.056 & absent & 0.003 & 0.006 \\
\hline 5 & 0.582 & 0.023 & 0.016 & 0.059 & 0.058 & 0.001 & 0.004 & 0.007 \\
\hline Average & $0.569 \pm 0.020$ & $0.022 \pm 0.002$ & $0.014 \pm 0.003$ & $0.049 \pm 0.017$ & $0.054 \pm 0.005$ & $0.003 \pm 0.002$ & $0.003 \pm 0.001$ & $0.006 \pm 0.002$ \\
\hline WHO standards & $0.5-5.0$ & 2 & 1 & 0.4 & 0.05 & 0.01 & 0.01 & 0.003 \\
\hline
\end{tabular}

Reading Tables 2(a)-2(c) shows that in all sampling sites. Water samples show very low levels of heavy metals that do not exceed the permissible values with the exception of $\mathrm{Cd}$. In fact, this mineral element present in concentrations higher than $0.003 \mathrm{mg} / \mathrm{l}$.

Figure 1 shows the rate of change of $\mathrm{Cd}$ concentrations of river water $\mathrm{Lu}$ - 


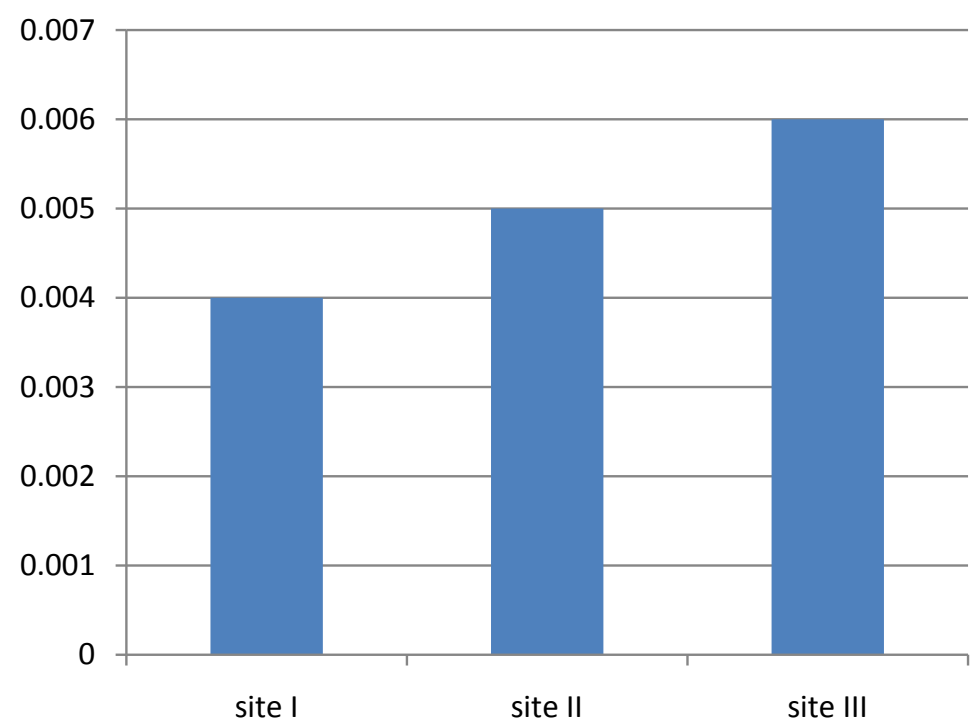

Figure 1. Level (in \%) of Cd in the different Sampling sites of the river water Lubumbashi.

bumbashi since site I to site III.

It is clear that the levels of Cd increase gradually from the site I $(0.004 \pm 0.001$ $\mathrm{mg} / \mathrm{L})$ at Site II $(0.005 \pm 0.001 \mathrm{mg} / \mathrm{l})$ and the site III $(0.006 \pm 0.002 \mathrm{mg} / \mathrm{l})$.

\section{Discussion}

Contamination of fresh water with heavy metals has become a serious matter, not only because it limits the use of water for domestic use but also for damages that it causes aquatic organisms [10].

In Katanga, the quality of being water is particularly threatened by the resumption of the mining is done without considering the protection criteria of recently introduced through the Congolese mining legislation environment. Wash water minerals and effluent treatment plants dumped untreated in rivers water contains heavy metals and residues of the different chemicals involved either in the process of extraction and separation, either in refining process [11] [12].

By observing the results in Table 1, it is clear that all $\mathrm{pH}$ values greater than 7; water samples are slightly basic and conform to drinking water standards set by the WHO has set an optimum between 6.5 and 9.5. Indeed, the $\mathrm{pH}$ is one of the physicochemical parameters for judging the potability of water [13]. Statistical analysis showed the existence of a significant difference in $\mathrm{pH}$ between I and III locations; these results are consistent with those of Fidèle Dimon et al. noted that a small variation in the $\mathrm{pH}$ of one station to another [2]. The values 8.66 and 10.51 for most express a slight basicity of the medium; liquid tributaries of the STL factory thus would influence the $\mathrm{pH}$ of the river water Lubumbashi by the contribution of the chemicals that make the river water more basic. This pyrometallurgical processing plant slag uses water of the river Lubumbashi in a cooling circuit of the plant pipes but also chemical reagents. such as $\mathrm{Ca}(\mathrm{OH})_{2}$ 
and $\mathrm{Na}_{2} \mathrm{CO}_{3}$ in the softening process of the water before being discharged into the river. These basic substances raise the $\mathrm{pH}$ of the water of the river. On leaving the factory exhaust the drain, these chemicals are mixed with water from the river and suffer dilution phenomenon. What could justify the non-existence of a difference significant between average Y2 and Y3.

The results for heavy metals revealed that they are in very low quantities in the river water Lubumbashi, except $\mathrm{Cd}$. Although unwanted metals in drinking water, $\mathrm{Cu}, \mathrm{Co}, \mathrm{Zn}, \mathrm{Mn}, \mathrm{Cr}, \mathrm{Pb}$ have levels that do not exceed the WHO guidelines. This can due to the fact that the $\mathrm{pH}$ also influences the solubility of metals in solution; gold as the $\mathrm{pH}$ of the river water Lubumbashi is more basic $(\mathrm{pH}>7)$, the metals tend to be precipitated [14].

In terms of cadmium, its concentration exceeds the normal value in $80 \%$ of samples analyzed in the site I; this concentration is too high for all cases studied in the II and III sites. These results corroborate those found by Katemo indicating accumulation cd preferentially in the gills of fish, results that confirm the pollution of the basin by Lufira effluent from the complex hydrometallurgical Shituru. The high concentration of Cd upstream as downstream at the point of mixing of river water and liquid effluents from the company STL shows that water pollution sources of the river Lubumbashi diversified. This is particularly the case of some artisanal miners who carry copper ore washing using water River in the vicinity of Lido camp. Indeed, the Cd is an impurity of zinc ore, lead and copper; as the industrial and artisanal exploitation of copper ores can significantly increase concentrations of $\mathrm{Cd}$ in the water of the river Lubumbashi. Gbagbo Onivogui study confirms that the comparison of concentrations of $\mathrm{Cd}$ and mercury are relatively higher than those in the upstream and al downstream of the city [15]. These metals are largely of origin anthropogenic and involve the spill by ruisselles of urban and industrial effluents in coastal lagoons. The gradual pace contents $\mathrm{Cd}$ confirms the contribution of liquid effluent from the company STL to pollution of the river Lubumbashi.

Our results show that the population using water from the Lubumbashi River is at risk of intoxication to this metal as cadmium is not an essential element in human metabolism because it has no known function in the human body [16]. Cadmium is therefore a non-essential metal for life. Once absorbed. it disperses into the body; The highest concentrations are mostly found in the kidneys and bones and lungs. The toxic effects of cadmium are numerous, but the main damage to the body following prolonged exposure in humans is impairment of renal function. Cadmium has a particular affinity for the kidney, because the latter has an endogenous synthesis of metallothioneins insufficient for all the capture. It accumulates in the form of $\mathrm{Cd} 2+$ ions and can cause damage to the tubules leading to proteinuria, which can ultimately lead to renal insufficiency, thus constituting a serious public health problem because. The majority of the population will not be able to procure means for a good management of this pathology [17].

Cadmium is to origin of the disease "Itai-Itai" described in Japan, characte- 
rized by kidney failure associated with the osteoporosis and the osteomalacia [18]. It was classified as Category 1 "carcinogenic to man" by IARC.

\section{Conclusions}

The results obtained in this work which aimed to evaluate the physicochemical and chemical characteristics and heavy metal contamination of the river Lubumbashi receiving discharges from Lubumbashi slag treatment plant (STL) showed that the $\mathrm{pH}$ of the river water meets the drinking water standards accepted by the WHO; however, the STL plant would contribute significantly to water alkalizing following its liquid effluents; $\mathrm{Cd}$. which displays very high concentrations, represents the element metal trace most dangerous and likely to contribute to the pollution of the river Lubumbashi. Industrial and artisanal mining operations constitute potential sources of pollution in $\mathrm{Cd}$.

Water is a natural resource around which maintains and develops life, must be closely monitored and strictly controlled.

\section{References}

[1] Water and Health (2003) WHO Guidelines on the Quality of Drinking Water.

[2] Dimon, F., Dovonou, F., Adjahossou, N., Chouti, W., Mama, D. and Alassane, A. (2014) Physical Characterization-Chemical Lake Ahémé (South Benin) and Highlighted the Sediment Pollution by Lead. Zinc and Arsenic Moussa Boukari. South African Journal of Chemical, 37, 36-42.

[3] Atolaye, B.O. and Aremu, M.O. (2007) Bioaccumulation of Some Trace Elements in the Body Parts of Fish Species Associated with Soil Sediment and Water from Eoemaganiâ Confluence in Nasarawa State, Nigeria. Electronic Journal of Environmental, Agricultural and Food Chemistry, 6, 2001-2008.

[4] Canli, M. and Kalay, Ö.A.M. (1998) Level of Heavy Metals (Cd, Pb, Cu, Cr and Ni) in Tissue of Cyprinus carpio, Barbus capito and Chondrostoma regium from the Seyhan River, Turkey. Turkish Journal of Zoology, 22, 149-157.

[5] Keumean, K.N., Bamba, S.B., Soro, G., Soro, N., Soro, B., Metongo and Biemi, J. (2013) Heavy Metal Concentration of Sediments of Estuary of the Comoé River in Grand-Bassam (South-East Coast'Ivory). Journal of Applied Bioscience, 61, 45304539.

[6] Lansgtone, W.J.G.R. and Burt Pope, N.D. (1999) Estuarine Coastal and Shelf. Science, 48, 519-540.

[7] Förstner, U. and Wittman, G.T.W. (1981) Metal Pollution in the Aquatic Environment. 2nd Edition, Springer-Verlag, Berlin, 486. https://doi.org/10.1007/978-3-642-69385-4

[8] Degbey, C., Makoutode, M., Fayomi, B. and De Brouwer, C. (2010) The Quality of Well Water in the Municipality of Abomey-Calavi in Benin. Environment, Risks \& Health, 7, 279-283.

[9] Rodier, J.L. (2005) An Analysis of Water, Natural Water, Waste Water, Sea Water: Physico-Chemistry, Bacteriology, Biology. 8th Edition, Dunod, Paris, 1382 p.

[10] Cobert, R.G. (1977) Effect of Coal Mining on Ground Water Quality and Area. Monongalia County. West Virginia. Science of the Total Environment, 8-12.

[11] SNC-Lavalin International (2003) Study on the Restoration of the Copper and 
Cobalt Mines in the Democratic Republic of Congo. M Preliminary Report-6708 (603.082), Montreal, 222 p.

[12] Vande Weghe, J.-P., Franssen, J., Kalambay, G., Kramkimel, J.D. and Musibono, D. (2005) Study "Environmental Profile (PEP) of the Democratic Republic of Congo". Delegation of the European Commission, EURATA, 228 p.

[13] Degremont (2005) Technical Diary of Water. 10th Edition, Lavoisier, Paris, Tome1, 131-145.

[14] Sigg, L., Behra, P. and Stumm, W. (2006) Chemistry Aquatic Environment. Natural Water Chemistry and Interfaces in the Environment. 4th Edition, Dunod, Paris, 484-491.

[15] Onivogui, G., Balde, S., Bangoura, K. and Barry, M.K. (2013) Risk Assessment of Pollution of Heavy Metals ( $\mathrm{Hg}, \mathrm{Cd}, \mathrm{Pb}, \mathrm{Co}, \mathrm{Ni}, \mathrm{Zn}$ ) Water and Sediment of Estuary Konkouré River (Republic of Guinea). SCIENCE Africa, 9, 36-44.

[16] Miquel, G. (2001) Effect of Heavy Metals on 'Environment and Health. Report 261, Parliamentary Office of Evaluation of Scientific and Technological Choices, 365 p.

[17] ATSDR (1999) Toxicological Profile for Mercury. Agency for Toxic Substances and Disease Registry. http://www.atsdr.cdc.gov/toxprofiles/tp46.pdf

[18] Payen, P. (2007) Risk Assessment for the Consumption of Recreational Walking Fishery Products in Lower-Normandy. Memory Engineer Sanitary Engineering, National School of Public Health, Rennes, 81 p.

Submit or recommend next manuscript to OALib Journal and we will provide best service for you:

- Publication frequency: Monthly

- 9 subject areas of science, technology and medicine

- Fair and rigorous peer-review system

- Fast publication process

- Article promotion in various social networking sites (LinkedIn, Facebook, Twitter, etc.)

- Maximum dissemination of your research work

Submit Your Paper Online: Click Here to Submit

Or Contact service@oalib.com 